\title{
Sexual dysfunction, depression, and anxiety in young women according to relationship status: an online survey
}

\author{
Disfunção sexual, depressão e ansiedade em mulheres jovens de acordo \\ com o status de relacionamento: uma pesquisa on-line
}

Valeska Martinho Pereira, ${ }^{1}$ Antonio Egidio Nardi, ${ }^{2}$ Adriana Cardoso Silva ${ }^{3}$

\begin{abstract}
Background: Sexual dysfunction is a common, still poorly understood problem among women. Being or not in a relationship seems to be a risk factor for sexual dysfunction.

Objectives: To evaluate the presence of sexual problems, anxiety, and depression in young women and to correlate findings with current relationship status (single, in a committed relationship, or married).

Methods: Data were collected trough an online survey from a total of 155 women aged between 20 and 29 years. Sociodemographic data were collected, and both the Hospital Anxiety and Depression scale and the Female Sexual Function Index were applied. Data were statistically analyzed using the chi-square and Kruskal-Wallis tests, and groups were compared in $2 \times 2$ matrices using the Mann-Whitney test.

Results: Single women showed a significantly higher prevalence of problems in the lubrication (45.3\%), orgasm (53.1\%), satisfaction $(67.2 \%)$, and pain $(50 \%)$ domains and also in total Female Sexual Function Index scores $(60.9 \%)$ in comparison with the other groups. Additionally, significantly higher depression

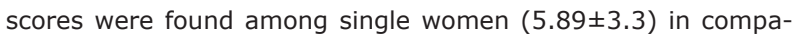
rison to those in a committed relationship (4.05 \pm 2.83$)$. Anxiety scores were similar in all groups.

Conclusion: Our findings suggest that single women have a poorer sexual function and are more likely to have mood disorders in comparison to their peers involved in stable relationships.

Keywords: Prevalence, sexual dysfunction, anxiety, depression, female.
\end{abstract}

\begin{abstract}
Resumo
Contexto: Disfunção sexual é um problema comum e ainda pouco compreendido entre mulheres. Estar ou não em um relacionamento parece ser um fator de risco para disfunção sexual.

Objetivo: Avaliar a presença de problemas sexuais, ansiedade e depressão em jovens mulheres e correlacionar os achados ao estado de relacionamento atual (solteiras, em relacionamento sério ou casadas).
\end{abstract}

Métodos: Dados foram coletados através de pesquisa on-line de um total de 155 mulheres com idade entre 20 e 29 anos. Foram coletados dados sociodemográficos, e a Escala Hospitalar de Ansiedade e Depressão e o Índice de Função Sexual Feminina foram aplicados. Os dados foram analisados através dos testes qui-quadrado e Kruskal-Wallis, e os grupos foram comparados dois a dois através do teste Mann-Whitney.

Resultados: Mulheres solteiras apresentaram uma prevalência significativamente maior de problemas nos domínios lubrificação $(45,3 \%)$, orgasmo $(53,1 \%)$, satisfação $(67,2 \%)$ e dor $(50 \%)$, e também no escore total do Índice de Função Sexual Feminina $(60,9 \%)$, em comparação aos outros grupos. Além disso, foram observados escores estatisticamente superiores para depressão em mulheres solteiras $(5,89 \pm 3,3)$ quando comparadas ao grupo relacionamento sério $(4,05 \pm 2,83)$. Os escores de ansiedade foram similares em todos os grupos.

Conclusão: Nossos resultados sugerem que mulheres solteiras têm um pior funcionamento sexual quando comparadas a seus pares envolvidos em relacionamentos estáveis e são mais propensas a apresentar transtornos de humor.

Descritores: Prevalência, disfunção sexual, ansiedade, depressão, mulheres.

\footnotetext{
${ }^{1}$ MSc, Graduate Program in Psychiatry and Mental Health, Instituto de Psiquiatria (IPUB), Universidade Federal do Rio de Janeiro (UFRJ), Rio de Janeiro, RJ, Brazil. Investigator, Laboratório de Pânico e Respiração, IPUB, UFRJ. National Science and Technology Institute for Translational Medicine (INCT-TM). ${ }^{2}$ PhD. Full professor, Graduate Program in Psychiatry and Mental Health, IPUB, UFRJ. Coordinator, Laboratório de Pânico e Respiração, IPUB, UFRJ. INCT-TM. ${ }^{3}$ PhD. Adjunct professor, Universidade Federal Fluminense (UFF), Niterói, RJ. Coordinator, Laboratório de Tanatologia e Psicometria, UFF. Vice coordinator, Laboratório de Pânico e Respiração, IPUB, UFRJ. INCT-TM.

Financial support: none.

Submitted May 16 2012, accepted for publication Aug 09 2012. No conflicts of interest declared concerning the publication of this article.

Suggested citation: Pereira VM, Nardi AE, Silva AC. Sexual dysfunction, depression, and anxiety in young women according to relationship status: an online survey. Trends Psychiatry Psychother. 2013;35(1):55-61.
} 


\section{Introduction}

The first model proposed to explain the human sexual response cycle comprised four distinct phases: excitement, plateau, orgasm, and resolution. ${ }^{1}$ Years later, another model emphasized the importance of desire in the human sexual response cycle. ${ }^{2}$ This current model is a combination of previous models and comprises the following four phases: desire, arousal, orgasm, and resolution. ${ }^{3}$

Sexual dysfunctions are impairments in the sexual response cycle or the presence of pain associated with sexual intercourse. ${ }^{3}$ Female sexual dysfunctions (FSD) can take the form of hypoactive sexual desire disorder, sexual aversion disorder, female sexual arousal disorder, female orgasmic disorder, dyspareunia, and vaginismus. In addition to these disorders, recently a new dysfunction called the persistent genital arousal disorder has also been described. ${ }^{4}$ Some risk factors for sexual dysfunction cited in the current literature include age, level of education, emotional problems, stress, and a history of sexual abuse. ${ }^{5}$

Anxiety seems to play an important role in FSD, but the relationship between both conditions is not completely clear. For instance, sexual worries and fears seem to impair sexual arousal, ${ }^{6}$ and nonsexual worries have been shown to affect sexual response. ${ }^{7}$ One study also found that women presenting complaints of vaginismus showed higher anxiety scores than controls. ${ }^{8}$

The literature suggests that depression has a close relationship with FSD, increasing the risk for development of the latter. In depressed women, hypoactive sexual desire disorder seems to be the most frequent dysfunction. ${ }^{9}$ Two studies conducted in Brazil reported the prevalence of any type of sexual dysfunction to be 28 and $49 \%$, respectively. ${ }^{10,11}$ Female orgasmic disorder presented rates between 18 and $29.3 \%,{ }^{10,12,13}$ and a prevalence of $26.7 \%$ was observed for hypoactive sexual desire disorder. ${ }^{11}$ Moreover, it has been reported that only $18.8 \%$ of women seek professional help for sexual disturbances. ${ }^{14}$

During pregnancy, the sexual functioning of women was found to be reduced in the third trimester. ${ }^{15}$ Women aged 40 to 65 years with at least 11 years of formal education showed the highest rates of sexual dysfunction among middle-aged women. ${ }^{16}$ The risk factors cited were lower socioeconomic and educational levels, whereas the predictors of good sexual functioning were having a sex partner and general well-being.

Most studies evaluating sexual dysfunction focus on differences across ages groups, while other suggested risk factors remain inconsistently studied. In this sense, studying women with similar sociodemographic characteristics provides a possibility to understand how other factors possibly interact and influence sexual function.
The objective of the present study was to evaluate the presence of sexual problems, anxiety and depression in young women aged 20 to 29 years and to correlate results with different relationship statuses (single, in a committed relationship/dating, or married), so as to identify possible differences in sexual functioning.

\section{Method}

\section{Participants and procedures}

This study used an online questionnaire to collect data. An advertise describing study aims and researcher information was posted on social networks and sexuality forums and discussion groups. An internet link was provided, and any woman could access and answer the survey. Data were collected for 2 months (May and June 2011).

Inclusion criteria were being female and aged 20 to 29 years. Questionnaires with missing data and women who did not match the age criterion were excluded. A total of 169 questionnaires were completed, and 155 were included in the analysis after application of exclusion criteria.

The study was approved by the Research Ethics Committee of Universidade Federal do Rio de Janeiro (protocol no. 20-02/07). Participation was voluntary and anonymous, and all participants were informed of the objectives of the study before starting to answer the questionnaire.

\section{Measures}

\section{Social demographics}

Sociodemographic data were collected using the standardized questionnaire Hospital Anxiety and Depression (HAD) scale and covered sexual orientation, marital status, religion, education level, having children, practice of physical activities, use of alcohol and tobacco, and psychiatric treatment.

The HAD scale is a self-reported instrument comprising 14 items divided into two subscales: HAD-A, which evaluates anxiety symptoms, and HAD-D, for depressive symptoms. ${ }^{13}$ Each subscale yields a separate score obtained by summing its items. The total HAD scale score is obtained by summing the final scores of each subscale. A cutoff point of 8 was used in each subscale to determine the presence or absence of depressive or anxiety disorder. The HAD scale has been translated to and validated in Brazilian Portuguese. ${ }^{17-19}$

\section{Female Sexual Function Index (FSFI)}

The FSFI is a 19-item scale that comprises six domains: desire, arousal, lubrication, orgasm, satisfaction, and 
pain. ${ }^{20}$ Each domain yields a score, obtained by summing individual item scores and multiplying the result by the domain factor. The total score is obtained by summing the final scores of all domains. The FSFI has also been validated for use in Brazilian populations. ${ }^{21,22}$ A cutoff of $\leq 26$ (total score) was used to determine the presence or absence of sexual dysfunction. ${ }^{23}$ Assessment of each individual domain considered a score below $65 \%$ of the total domain (3.9 points) as suggestive of dysfunction in that particular domain. ${ }^{24}$

\section{Data analysis}

Sociodemographic data were analyzed using descriptive statistics and expressed as absolute values and percentages or as means and standard deviation (SD). Contingency tables were analyzed using the chisquare test, Fisher's exact test, and analysis of variance (ANOVA). Significance was set at $p<0.05$.

Inter-group differences in the prevalence of sexual dysfunction, anxiety, and depression were determined using the chi-square and Kruskal-Wallis $\mathrm{H}$ tests. When a statistically significant difference was found using the
Kruskal-Wallis test, $2 \times 2$ comparisons were performed using the Mann-Whitney test to identify the difference location. Again, significance was set at $p<0.05$.

\section{Results}

The 155 women were divided into three groups, as follows: single ( $n=64,41.3 \%)$, in a committed relationship ( $n=64,41.3 \%)$, and married $(n=27,17.4 \%)$. Mean age was $24.9 \pm 2.675$ years. The majority of women were heterosexual $(84.5 \%)$, had no religion $(38.1 \%)$, no children $(89.7 \%)$, and complete college education (81.3\%). Most women had no history of psychiatric treatment $(73.5 \%)$, rarely used alcohol $(49.7 \%)$, did not use tobacco $(90.3 \%)$, and did not practice physical activities (58.1\%).

Descriptive data for all three groups (single, in a committed relationship, and married) are presented in Table 1 and reveal a similar distribution of most variables (education level, religion, practice of physical activity, use of alcohol and tobacco, and psychiatric treatment). The only variables showing statistically significant difference between the groups were age and having/not having children.

Table 1 - Descriptive data of subjects according to relationship status

\begin{tabular}{|c|c|c|c|c|c|c|}
\hline & Single $(n=64)$ & $\begin{array}{c}\text { In a committed } \\
\text { relationship }(n=64)\end{array}$ & Married $(n=27)$ & df & F or $\chi^{2}$ & $\mathbf{p}$ \\
\hline Age, mean (SD) & $24.72(2.62)$ & $24.55(2.69)$ & $26.15(2.47)$ & 2 & 3.77 & 0.02 \\
\hline Sexual orientation, $\mathrm{n}(\%)$ & & & & 4 & 3.88 & 0.42 \\
\hline Heterosexual & $51(79.7)$ & $55(85.9)$ & $25(92.6)$ & & & \\
\hline Homosexual & $5(7.9)$ & $2(3.1)$ & - & & & \\
\hline Bisexual & $8(12.5)$ & $7(10.9)$ & $2(7.4)$ & & & \\
\hline Religion, n (\%) & & & & 8 & 12.5 & 0.13 \\
\hline No religion & $21(32.8)$ & $31(48.4)$ & $7(25.9)$ & & & \\
\hline Catholic & $17(26.6)$ & $18(28.1)$ & $11(40.7)$ & & & \\
\hline Protestant & $8(12.5)$ & $2(3.1)$ & $5(18.5)$ & & & \\
\hline Spiritist & $16(25)$ & $11(17.2)$ & $4(14.8)$ & & & \\
\hline Other & $2(3.1)$ & $2(3.1)$ & - & & & \\
\hline Education level, n (\%) & & & & 4 & 5.15 & 0.27 \\
\hline High school & $3(4.7)$ & $3(4.7)$ & $3(11.1)$ & & & \\
\hline College & $56(87.5)$ & $49(76.6)$ & $21(77.8)$ & & & \\
\hline Graduate studies & $5(7.8)$ & $12(18.8)$ & $3(11.1)$ & & & \\
\hline Children, $\mathrm{n}(\%)$ & & & & 2 & 32.76 & $<0.01$ \\
\hline Yes & $2(3.1)$ & $3(4.7)$ & $11(40.7)$ & & & \\
\hline No & $62(96.9)$ & $61(95.3)$ & $16(59.3)$ & & & \\
\hline Physical activity, n (\%) & & & & 2 & 2.83 & 0.42 \\
\hline Yes & $26(40.6)$ & $31(48.4)$ & $8(29.6)$ & & & \\
\hline No & $38(59.4)$ & $33(51.6)$ & $19(70.4)$ & & & \\
\hline Alcohol use, n (\%) & & & & 6 & 14.12 & 0.28 \\
\hline Never & $8(12.5)$ & $8(12.5)$ & $6(22.2)$ & & & \\
\hline Rarely & $29(45.3)$ & $32(50)$ & $16(59.3)$ & & & \\
\hline Regularly & $18(28.1)$ & $23(35.9)$ & $5(18.5)$ & & & \\
\hline Frequently & $9(14.1)$ & $1(1.6)$ & - & & & \\
\hline Tobacco use, n (\%) & & & & 2 & 0.99 & 0.60 \\
\hline Yes & $8(12.5)$ & $5(7.8)$ & $2(7.4)$ & & & \\
\hline No & $56(87.5)$ & $59(92.2)$ & $25(92.6)$ & & & \\
\hline Psychiatric treatment, n (\%) & & & & 4 & 1.35 & 0.85 \\
\hline Never & $47(73.4)$ & $48(75)$ & $19(70.4)$ & & & \\
\hline Has been treated before & $12(18.8)$ & $11(17.2)$ & $7(25.9)$ & & & \\
\hline Currently under treatment & $5(7.8)$ & $5(7.8)$ & $1(3.7)$ & & & \\
\hline
\end{tabular}

$\chi^{2}=$ chi-square test; $d f=$ degrees of freedom; $\mathrm{F}=$ Fisher's exact test; SD = standard deviation. 
Table 2 presents the total prevalence rates for anxiety, depression, each FSFI domain and the FSFI total score. Of the 155 subjects, 64 (41.3\%) were considered to have sexual dysfunction. Because more than one domain may be affected in the same subject, the sum of rates exceeds $100 \%$.

Table 2 - Prevalence of sexual dysfunction in the total sample

\begin{tabular}{lcc}
\hline Domain & $\mathbf{n}$ & \% \\
\hline Anxiety & 56 & 36.1 \\
Depression & 34 & 21.9 \\
Desire & 82 & 52.9 \\
Arousal & 57 & 36.8 \\
Lubrication & 47 & 30.3 \\
Orgasm & 61 & 39.4 \\
Satisfaction & 63 & 40.6 \\
Pain & 51 & 32.9 \\
FSFI total score & 64 & 41.3 \\
\hline
\end{tabular}

FSFI $=$ Female Sexual Function Index.

Results obtained with the HAD scale and the FSFI in each group are shown in Table 3. The following variables were additionally examined in women who reached the cutoff point for any of the variables assessed. Intergroup differences were described using the Kruskal-
Wallis $\mathrm{H}$ test, because the assumptions of parametric tests were equivalent and did not meet the requirements for degrees of freedom or $p$ values. The prevalence rates obtained for the different groups are also presented in Table 3.

Statistically significant differences were observed between the groups in all evaluated variables, except for the FSFI desire domain and anxiety, which were similar across the three groups. Table 4 presents the comparison of variables between different pairs of groups $(2 \times 2$ comparison), in order to show where the differences are located.

According to Table 4, single women and those in a committed relationship showed statistically significant differences in almost all variables, except for anxiety and the FSFI desire domain. In the comparison of single vs. married women, results were similar for anxiety, desire, and depression, with no statistically significant differences. Finally, an inverse relationship was observed when comparing women in a committed relationship vs. married women, with similar characteristics overall and a statistically significant different only in the FSFI satisfaction domain.

Table 3 - Results obtained for HAD-A, HAD-D, FSFI domains, and FSFI total score, expressed as means and standard deviation, followed by $n$ and percentage of subjects who reached the cutoff points, according to relationship status

\begin{tabular}{|c|c|c|c|c|c|c|c|c|c|}
\hline & \multicolumn{2}{|c|}{$\begin{array}{c}\text { Single } \\
(n=64)\end{array}$} & \multicolumn{2}{|c|}{$\begin{array}{c}\text { In a committed } \\
\text { relationship }(n=64)\end{array}$} & \multicolumn{2}{|c|}{$\begin{array}{l}\text { Married } \\
(n=27)\end{array}$} & \multirow[b]{2}{*}{ df } & \multirow[b]{2}{*}{$\chi^{2}$} & \multirow[b]{2}{*}{$\mathbf{p}$} \\
\hline & Mean \pm SD & n (\%) & Mean \pm SD & n (\%) & Mean \pm SD & n (\%) & & & \\
\hline Anxiety & $6.8 \pm 3.515$ & $23(35.9)$ & $6.55 \pm 3.82$ & $21(32.8)$ & $6.78 \pm 3.17$ & $12(44.4)$ & 2 & 0.56 & 0.75 \\
\hline Depression & $5.89 \pm 3.38$ & $21(32.8)$ & $4.05 \pm 2.83$ & $9(14.1)$ & $4.78 \pm 2.70$ & $4(14.8)$ & 2 & 10.47 & $<0.01$ \\
\hline Desire & $3.98 \pm 1.34$ & $30(46.9)$ & $3.95 \pm 1.05$ & $38(59.4)$ & $3.95 \pm 0.85$ & $14(51.9)$ & 2 & 0.10 & 0.94 \\
\hline Arousal & $3.16 \pm 2.31$ & $32(50)$ & $4.49 \pm 1.41$ & $17(26.6)$ & $4.5 \pm 0.94$ & $8(26.6)$ & 2 & 9.30 & 0.01 \\
\hline Lubrication & $3.38 \pm 2.55$ & $29(45.3)$ & $4.91 \pm 1.48$ & $12(18.8)$ & $4.92 \pm 1.29$ & $6(22.2)$ & 2 & 10.56 & $<0.01$ \\
\hline Orgasm & $3.01 \pm 2.44$ & $34(53.1)$ & $4.38 \pm 1.69$ & $15(23.4)$ & $4.16 \pm 1.57$ & $12(44.4)$ & 2 & 8.91 & 0.01 \\
\hline Satisfaction & $2.82 \pm 1.98$ & $43(67.2)$ & $4.84 \pm 1.50$ & $12(18.8)$ & $4.42 \pm 1.34$ & $8(29.6)$ & 2 & 32.90 & $<0.01$ \\
\hline Pain & $3.06 \pm 2.72$ & $32(50)$ & $4.60 \pm 1.94$ & $15(23.4)$ & $5.09 \pm 1.11$ & $4(14.8)$ & 2 & 11.43 & $<0.01$ \\
\hline FSFI total score & $19.43 \pm 11.19$ & 39 (60.9) & $27.20 \pm 7.57$ & $16(25)$ & $27.06 \pm 5.31$ & $9(33.3)$ & 2 & 16.57 & $<0.01$ \\
\hline
\end{tabular}

$\chi^{2}=$ chi-square test; $\mathrm{df}=$ degrees of freedom; FSFI = Female Sexual Function Index; HAD-A = Hospital Anxiety and Depression - Anxiety Symptoms; HAD-D $=$ Hospital Anxiety and Depression - Depression Symptoms; SD = standard deviation.

Table 4 - Group comparison $(2 \times 2)$ for anxiety, depression, FSFI domains, and FSFI total score

\begin{tabular}{|c|c|c|c|c|c|c|c|c|c|}
\hline & \multicolumn{3}{|c|}{$\begin{array}{l}\text { Single vs. in } \\
\text { a committed relationship }\end{array}$} & \multicolumn{3}{|c|}{ Single vs. married } & \multicolumn{3}{|c|}{$\begin{array}{l}\text { In a committed } \\
\text { relationship vs. married }\end{array}$} \\
\hline & $\mathbf{U}$ & z & p & $\mathbf{U}$ & $\mathbf{z}$ & $\mathbf{p}$ & $\mathbf{U}$ & $\mathbf{z}$ & $\mathbf{p}$ \\
\hline Anxiety & 1940.50 & -0.51 & 0.61 & 824.00 & -0.35 & 0.77 & 786.00 & -0.68 & 0.49 \\
\hline Depression & 1384.50 & -3.18 & $<0.01$ & 708.50 & -1.35 & 0.17 & 712.00 & -1.33 & 0.18 \\
\hline Desire & 1986.50 & -3.78 & 0.77 & 843.50 & -0.18 & 0.86 & 846.00 & -0.16 & 0.87 \\
\hline Arousal & 1440.00 & -2.92 & $<0.01$ & 653.50 & -1.84 & 0.06 & 778.00 & -0.75 & 0.45 \\
\hline Lubrication & 1437.00 & -2.96 & $<0.01$ & 597.00 & -2.36 & 0.02 & 858.50 & -0.05 & 0.96 \\
\hline Orgasm & 1475.00 & -2.75 & $<0.01$ & 632.00 & -2.03 & 0.04 & 778.00 & -0.75 & 0.45 \\
\hline Satisfaction & 926.50 & -5.38 & $<0.01$ & 471.00 & -3.42 & $<0.01$ & 632.00 & -2.04 & 0.04 \\
\hline Pain & 1455.00 & -2.93 & $<0.01$ & 563.00 & -2.70 & $<0.01$ & 830.50 & -0.30 & 0.76 \\
\hline FSFI total score & 1254.50 & -3.78 & $<0.01$ & 546.50 & -2.76 & $<0.01$ & 775.50 & -0.77 & 0.44 \\
\hline
\end{tabular}

FSFI = Female Sexual Function Index. 


\section{Discussion}

The groups selected for analysis showed similarity in most sociodemographic variables assessed, except for age and having or not having children. These two variables were slightly higher in the married group, which was an expected finding, as it is more likely to find married women among older individuals. The higher frequency of children among married women was also expected in comparison to the non-married groups. Because all three groups were quite homogenous for all other variables, possible differences could be explained by the different current relationship status of the participants.

A review of data collected in the World Mental Health surveys revealed prevalence rates for any type of psychiatric disorder ranging from 18.1 to $36.1 \%$. Anxiety disorders were the most prevalent ones, with a 12-month rate ranging from 6.5 to $12.1 \%$. Depression, in turn, showed prevalence rates from 3.4 to $6.8 \% .{ }^{25}$ Another study reported anxiety and depression prevalence rates of 6 and $4.5 \%$, respectively. ${ }^{26}$

The present study assessed anxiety and depressive symptoms appearing over 1 month prior to the survey and found substantially high rates, namely, 36.1\% for anxiety and $21.9 \%$ for depression. Even though the instrument used in our study does not allow to diagnose depressive or anxiety disorders, it suggests the presence of mood abnormalities among our respondents, especially in those with sexual complaints. Approximately $30 \%$ of the women in our sample was or had already been under psychiatric treatment, suggesting a higher risk of psychiatric disorders in the group assessed. The diagnostic confirmation of these disorders was beyond the scope of the present study.

A previous study assessing the relationship between marital status and mental illness reported that, overall, married people were more likely to have a better mental health and, consequently, a lower prevalence of psychiatric disorders. ${ }^{27}$ Another study demonstrated higher rates of mental disorders among single people and in those who live alone. ${ }^{28}$ Marital status was identified as a predictor of better mental health, even though this relationship may change as age progresses. ${ }^{29}$

An unexpected finding in our study was a higher, albeit not significant, prevalence of anxiety in married women $(44.4 \%)$ vs. those not married (single, 35.9\%; in a committed relationship, 32.8\%). The literature suggests exactly the opposite, i.e., that married people tend to have a better mental health. ${ }^{28,29}$ Depression was more prevalent in the single group (32.8\%), which also showed the highest mean score in the HAD-D $(5.89 \pm 3.38)$. When compared to women in a committed relationship, single women showed a statistically significant difference in depression scores ( $U$ $[z=-3.18]$ $=1384.5 ; p<0.01)$; this difference was not confirmed in the comparison between single and married women.

The rates of sexual dysfunction found in our sample are similar to those reported in previous epidemiological studies. ${ }^{10-12,30-32}$ When analyzing FSFI scores for different domains, desire problems were more frequently identified, as also in a previous study. ${ }^{11}$ Even though desire was the most prevalent problem in our sample, no statistically significant difference was found across the groups.

Desire problems were higher among married women $(51.9 \%)$ and in those in a committed relationship $(59.4 \%)$, but the difference was not statistically significant $(U[z=-0.18]=843.50 ; p=0.86)$. This result could be explained from the perspective of a new model of female sexual response cycle. Women in a committed relationship have other motivations to engage in sexual intercourse rather than sexual desire, e.g., intimacy and emotional bonding with their partners; this is one of the reasons possibly behind the higher rates of desire problems in married and committed women vs. single women. ${ }^{33}$

In fact, married women and those in a committed relationship showed similar rates and scores in almost all FSFI domains, as observed in Table 4. The only exception was the satisfaction domain, where a statistically significant difference was observed $(U[z=-2.04]=$ $632 ; p=0.04$ ). Single women also showed a statistically significant difference in this domain when compared to the other groups: single vs. committed, $U(z=-5.38)=$ $926.5(p<0.01)$, and single vs. married, $U(z=-3.42)$ $=471(p=0.01)$.

The orgasm domain showed high results in this study, with a prevalence rate as high as $53.1 \%$ among single women and $44.4 \%$ among married women; women in a committed relationship, in turn, showed a prevalence of $23.4 \%$. These rates are higher than others previously published. ${ }^{30,34,35}$ Another interesting finding was that the single group showed the highest prevalence rate but the

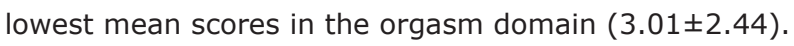

Single women also showed a higher prevalence of disturbances in the lubrication domain (45.3\%), in addition to a statistically significant difference when compared to the other two groups. Other studies have reported lubrication problem rates ranging from 12.5 to $45.4 \% .^{24,35,36}$

Finally, sexual pain is a frequent problem among women, with rates ranging from 12.8 to $42.9 \% .^{37,38}$ Previous studies have suggested that women aged 20 to 29 years are more likely to experience pain during sexual intercourse. ${ }^{24,36}$ In this study, single women 
reported a $50 \%$ prevalence rate for sexual pain, at a statistically significant difference when compared to the other groups (Table 4).

Some limitations of the present online-based study deserve to be discussed. First of all, our questionnaires were posted on forums, discussion groups, and communities focusing on female sexual function. As a result, anybody having access to the survey link could answer the questionnaire. No identification data were requested, in an attempt to avoid losses. Finally, another limitation was that only women with internet access could participate in the study. Although the internet has been increasingly reaching different strata, this could be an important determinant of the responses obtained.

Because the objective of the present study was to compare sexual function in women within the same age range and in with different relationship statuses, we decided not to exclude women with no sex partners. Single women tend to have more casual sex; therefore, we believe that an important body of data would be disregarded if only women with recent sexual activity had been included. In other words, our aim was to evaluate how the presence or absence of sexual life might impact mental health.

In sum, the results obtained in this study suggest that single women have a poorer sexual function when compared to women in the same age group and involved in either committed relationships or marriage; the latter two groups, in turn, seem to have similar levels of sexual functioning. These findings underscore the need to take into account the distinct characteristics of single women when planning strategies aimed at this population.

The findings also incite the discussion about risk factors associated not only with specific age groups, but also with other (biological, social, cultural) aspects that play important roles in human sexuality. Future studies investigating the association between relationship or marital status, quality of life, sexual function, and psychiatric disorders are needed to improve our understanding of other factors that may interfere with female sexual function. Also, studies focusing on current relationship patterns in different populations may shed some light on the mechanisms through which mood may affect or be affected by sexual functioning.

\section{References}

1. Masters WH, Johnson VE. Human sexual response. Boston: Little, Brown; 1966.

2. Kaplan HS. Disorders of sexual desire and other new concepts and techniques in sex therapy. New York: Brunner/ Mazel; 1979.

3. American Psychiatric Association. Diagnostic and Statistical Manual of Mental Disorders. Washington: American Psychiatric Association; 1994.

4. Leiblum SR, Nathan SG. Persistent sexual arousal syndrome: a newly discovered pattern of female sexuality. J Sex Marital Ther. 2001;27:365-80.

5. Laumann EO, Paik A, Rosen RC. Sexual dysfunction in the United States: prevalence and predictors. JAMA. 1999;281:537-44.

6. Barlow DH. Causes of sexual dysfunction: the role of anxiety and cognitive interference. J Consult Clin Psychol. 1986;54:140-8.

7. Brody S, Laan E, van Lunsen RH. Concordance between women's physiological and subjective sexual arousal is associated with consistency of orgasm during intercourse but not other sexual behavior. J Sex Marital Ther. 2003;29:15-23.

8 . Watts G, Nettle D. The role of anxiety in vaginismus: a casecontrol study. J Sex Med. 2010;7:143-8.

9. Fabre LF, Smith LC. The effect of major depression on sexual function in women. J Sex Med. 2012;9:231-9.

10. Prado DS, Lins VP, Azevedo TI. Prevalência de disfunção sexual em dois grupos de mulheres de diferentes níveis socioeconômicos. Rev Bras Ginecol Obstet. 2010;32:139-43.

11. Abdo $\mathrm{CH}$, Oliveira WM Jr, Moreira ED Jr, Fittipaldi JA. Prevalence of sexual dysfunctions and correlated conditions in a sample of Brazilian women--results of the Brazilian study on sexual behavior (BSSB). Int J Impot Res. 2004;16:160-6.

12. Abdo CH, Oliveira WM, Moreira ED, Fittipaldi JA. Perfil sexual da população brasileira: resultados do Estudo do Comportamento Sexual (ECOS) do brasileiro. Rev Bras Med. 2002;59:250-7.

13. Carneiro AL, de AI, Ramos MM. [Female sexual dysfunction prevalence in a family planning clinic at a university hospital located in Recife, Pernambuco]. Rev Bras Saude Mater Infant. 2007; 7:143-50.

14. Moreira ED Jr, Brock G, Glasser DB, Nicolosi A, Laumann EO, Paik $A$, et al. Help-seeking behaviour for sexual problems: the global study of sexual attitudes and behaviors. Int J Clin Pract. 2005;59:6-16.

15. Lima AP, Salles AA, Cardoso AR, Amed AM, Souza ED, Camano L. Prevalence of sexual dysfunction during pregnancy. Rev Assoc Med Bras. 2009;55:563-8.

16. Valadares AL, Pinto-Neto AM, Osis MJ, Sousa MH, CostaPaiva L, Conde DM. Prevalence of sexual dysfunction and its associated factors in women aged 40-65 years with 11 years or more of formal education: a population-based household survey. Clinics (Sao Paulo). 2008;63:775-82. 
17. Zigmond AS, Snaith RP. The hospital anxiety and depression scale. Acta Psychiatr Scand. 1983;67:361-70.

18. Marcolino JA, Suzuki FM, Cunha LA, Gozzani JL, Mathias LA. Medida da ansiedade e da depressão em pacientes no pré-operatório. Estudo comparativo. Rev Bras Anestesiol. 2007; 57:157-66.

19. Marcolino JA, Mathias LA, Filho LP, Guaratini AA, Suzuki FM, Cunha LA. Escala hospitalar de ansiedade e depressão: estudo da validade de critério e da confiabilidade com pacientes no pré-operatório. Rev Bras Anestesiol. 2007;57:52-62.

20. Rosen R, Brown C, Heiman J, Leiblum S, Meston C, Shabsigh $R$, et al. The Female Sexual Function Index (FSFI): a multidimensional self-report instrument for the assessment of female sexual function. J Sex Marital Ther. 2000;26:191-208.

21. Rocio RD, Dambros M, Rodrigues PC, Thiel M, Zanettini CL, Fatima MR. Tradução para português, adaptação cultural e validação do Female Sexual Function Index. Rev Bras Ginecol Obstet. 2008;30:504-10.

22. Carvalho RD, Vieira EM, Rodrigues OM, Souza CD. [Crosscultural adaptation of the Female Sexual Function Index.]. Cad Saude Publica. 2008;24:416-26.

23. Wiegel $M$, Meston $C$, Rosen R. The female sexual function index (FSFI): cross-validation and development of clinical cutoff scores. J Sex Marital Ther. 2005;31:1-20.

24. Safarinejad MR. Female sexual dysfunction in a populationbased study in Iran: prevalence and associated risk factors. Int J Impot Res. 2006;18:382-95.

25. Kessler RC, Aguilar-Gaxiola S, Alonso J, Chatterji S, Lee S, Ormel J, et al. The global burden of mental disorders: an update from the WHO World Mental Health (WMH) surveys. Epidemiol Psichiatr Soc. 2009;18:23-33.

26. Andrade L, Walters EE, Gentil V, Laurenti R. Prevalence of ICD-10 mental disorders in a catchment area in the city of São Paulo, Brazil. Soc Psychiatry Psychiatr Epidemiol. 2002;37:316-25.

27. Williams DR, Takeuchi DT, Adair RK. Marital status and psychiatric disorders among blacks and whites. J Health Soc Behav. 1992;33:140-57.

28. McLaughlin KA, Xuan Z, Subramanian SV, Koenen KC. Statelevel women's status and psychiatric disorders among US women. Soc Psychiatry Psychiatr Epidemiol. 2011; 46:1161-71.
29. Patten SB, Wang JL, Williams JV, Currie S, Beck CA, Maxwell $\mathrm{CJ}$, et al. Descriptive epidemiology of major depression in Canada. Can J Psychiatry. 2006;51:84-90.

30. Kessler RC, Berglund P, Demler O, Jin R, Merikangas $\mathrm{KR}$, Walters EE. Lifetime prevalence and age-of-onset distributions of DSM-IV disorders in the National Comorbidity Survey Replication. Arch Gen Psychiatry. 2005;62:593-602.

31. Simons JS, Carey MP. Prevalence of sexual dysfunctions: results from a decade of research. Arch Sex Behav. 2001;30:177-219.

32. Shifren JL, Monz BU, Russo PA, Segreti A, Johannes CB. Sexual problems and distress in United States women: prevalence and correlates. Obstet Gynecol. 2008;112:970-8.

33. Basson R. The female sexual response: a different model. J Sex Marital Ther. 2000;26:51-65.

34. Najafabady MT, Salmani Z, Abedi P. Prevalence and related factors for anorgasmia among reproductive aged women in Hesarak, Iran. Clinics (Sao Paulo). 2011;66:83-6.

35. Hisasue $\mathrm{Si}$, Kumamoto $Y$, Sato $Y$, Masumori N, Horita $H$, Kato $R$, et al. Prevalence of female sexual dysfunction symptoms and its relationship to quality of life: a Japanese female cohort study. Urology. 2005;65:143-8.

36. Song SH, Jeon H, Kim SW, Paick JS, Son H. The prevalence and risk factors of female sexual dysfunction in young Korean women: an internet-based survey. J Sex Med. 2008; 5:1694-701.

37. Ponholzer A, Roehlich M, Racz U, Temml C, Madersbacher S. Female sexual dysfunction in a healthy Austrian cohort: prevalence and risk factors. Eur Urol. 2005;47:366-74, discussion 374-5.

38. Oksuz E, Malhan S. Prevalence and risk factors for female sexual dysfunction in Turkish women. J Urol. 2006;175:654-8.

\section{Correspondence}

Valeska Martinho Pereira

Instituto de Psiquiatria, Laboratório de Pânico e Respiração

Rua Visconde de Pirajá, 407/702

22410-003 - Rio de Janeiro, RJ - Brazil

Tel. : + 55 (21) 2521.6147

Fax: +55 (21) 2523.6839

E-mail: valeskapereira@gmail.com 